Jurnal Kesehatan

Volume 12, Nomor 3, Tahun 2021

ISSN 2086-7751 (Print), ISSN 2548-5695 (Online)

http://ejurnal.poltekkes-tjk.ac.id/index.php/JK

\title{
Literature Review: Rencana Perawatan pada Gigi Anomali Anatomi Microdontia
}

\section{Literature Review: Management Treatment of Anatomical Anomalies Teeth Microdontia}

\author{
Ahmad Ferza Fauzan ${ }^{1}$, Bambang Tri Hartomo ${ }^{2}$ \\ ${ }^{1,2}$ Fakultas Kedokteran, Universitas Jenderal Soedirman Purwokerto, Indonesia \\ ${ }^{1,2}$ Rumah Sakit Gigi dan Mulut, Universitas Jenderal Soedirman Purwokerto, Indonesia
}

ARTICLE INFO

\section{Article history}

Received date

08 Apr 2021

Revised date

20 Jun 2021

Accepted date

08 Sep 2021

Keywords:

Crown;

Dental anomalies;

Microdontia;

PFM;

Prothesa.

\section{Kata kunci:}

Crown;

Anomali gigi;

Microdontia;

PFM;

Gigi tiruan

\author{
ABSTRACT/ ABSTRAK
}

Microdontia is a tooth size abnormality that indicates a smaller than normal tooth size, it can also be accompanied by deformities, namely with a cone or cone shape. The role of restoration in dentistry must fulfill various aspects, namely aesthetic needs and functions. This literature aims to provide information and an overview of the selection of the right treatment for patients with microdontia anatomical anomalies. Denture crown treatment is expected to meet consumer satisfaction in terms of aesthetics, phonation and mastication. Denture crowns or crowns can be made of several materials, namely metal, composite, acrylic and porcelain, besides a combination of the two materials such as metal-porcelain or what is often called porcelain fused to metal (PFM). PFM is used to restore severe tooth decay to protect the remaining tooth tissue structure, maintain occlusion and provide aesthetic value.

\begin{abstract}
Mikrodontia merupakan kelainan ukuran gigi yang menunjukkan ukuran gigi yang lebih kecil dari normal, dapat juga disertai kelainan bentuk yaitu dengan bentuk kerucut atau konus. Peranan restorasi dalam kedokteran gigi harus memenuhi berbagai aspek yaitu kebutuhan estetik dan fungsi. Tulisan ini bertujuan untuk memberikan infomasi dan gambaran pemilihan perawatan yang tepat bagi penderita gigi anomali anatomi microdontia. Perawatan mahkota gigi tiruan diharapkan dapat memenuhi kepuasan konsumen baik dalam aspek estetika, fonasi dan mastikasi. Mahkota gigi tiruan atau crown dapat terbuat dari beberapa bahan yaitu logam, komposit, akrilik, dan porcelain, selain itu kombinasi dari kedua bahan seperti logam-porselenatau yang sering disebut porcelain fused to metal (PFM). PFM digunakan untuk merestorasi kerusakan gigi yang parah untuk melindungi struktur jaringan gigi yang tersisa, menjaga oklusi dan memberikan nilai estetik.
\end{abstract}

Corresponding Author:

Bambang Tri Hartomo

Fakultas Kedokteran, Universitas Jenderal Soedirman, Indonesia.

Email: bambang.hartomo@unsoed.ac.id

\section{PENDAHULUAN}

Mikrodontia merupakan kelainan ukuran gigi yang menunjukkan ukuran gigi yang lebih kecil dari normal. Umumnya keadaan ini terjadi pada gigi tetap, pada gigi sulung sangat jarang terjadi. Terdapat dua tipe mikrodontia yaitu tipe 1 true microdontia dan pseudo microdontia. True microdontia adalah ukuran gigi yang lebih kecil dari normal pada rahang yang berukuran normal, sedangkan pseudo mikrodontia adalah seluruh gigi yang terlihat kecil pada rahang yang berukuran besar. Berdasarkan banyak gigi yang terkena dikenal ada localized microdontia dan 
generalized microdontia. True generalized microdontia adalah keadaan seluruh gigi berbentuk normal dengan ukuran lebih kecil dari normal, sedangkan generalized relative microdontia adalah seluruh gigi berukuran lebih kecil dari normal dengan rahang lebih besar dari 2 normal. Etiologi mikrodontia adalah multifactorial (Laskaris, 2000; Malleshi, et al., 2014).

Mikrodontia terjadi sebagai akibat adanya disrupsi pada saat awal pertumbuhan dan perkembangan gigi yaitu pada tahap bud stage pada minggu kedelapan masa prenatal. Disrupsi perkembangan gigi mengakibatkan baik ameloblas dan odontoblas sebagai sel pembentuk gigi tidak berdiferensiasi secara optimal sehingga menghasilkan bentuk gigi yang lebih kecil dari normal. Banyak faktor yang memengaruhi terjadinya anomali ukuran gigi. Faktor utama yang memengaruhi anomali pada gigi adalah faktor genetik dan lingkungan. Faktor genetik, memengaruhi benih gigi, yang sifat diturunkan oleh gen dari orang tua, sedangkan faktor lingkungan memengaruhi gigi tersebut setelah erupsi, yaitu bersifat mekanis dan kimiawi. Manifestasi klinis memperlihatkan ukuran mahkota yang lebih kecil, terutama insisif lateral lebih kecil daripada variasi normal disertai bentuk yang mengerucut atau conical teeth (Syarif, 2009).

Bentuk gigi yang abnormal atau peg shaped pada gigi insisif lateral secara estetis sangat tidak baik dikarenakan gigi bentuk dan ukurannya lebih kecil dibandingkan dengan gigi gigi yang lain. Penatalaksanaan gigi yang mengalami peg shape dapat dilakukan pada bagian prosthodontia. Pada bidang ilmu prosthodontia perawatan yang biasa dilakukan adalah dengan cara preparasi gigi dan menggantinya dengan menggunakan mahkota gigi tiruan dengan bahan all porcelain ataupun PFM (Gupta, 2019).

Tulisan ini bertujuan untuk memberikan infomasi dan gambaran pemilihan perawatan yang tepat bagi penderita gigi anomali anatomi microdontia. Perawatan mahkota gigi tiruan diharapkan dapat memenuhi kepuasan konsumen baik dalam aspek estetika, fonasi dan mastikasi.

\section{PEMBAHASAN}

Mikrodontia adalah kelainan ukuran pada gigi yang menunjukan perbedaan ukuran dengan gigi normal biasanya gigi yang terlihat lebih kecil dari ukuran normal. Penyebab utama dari mikrodontia adalah genetik dan kelainan ketika tumbuh kembang. faktor genetik dapat memengaruhi kelainan pada bentuk, jumlah, mineralisasi gigi, lokasi, dan posisi erupsi benih gigi. Disrupsi pada gigi geligi terjadi saat awal pertumbuhan dan perkembangan gigi yaitu pada tahap bud stage di minggu kedelapan masa prenatal. Gangguan yang terjadi berupa obstruksi lamina dentalis sehingga terjadi gangguan proliferasi dari bakal ameloblas dan odontoblas. Disrupsi perkembangan gigi mengakibatkan baik ameloblas dan odontoblas sebagai sel pembentuk gigi tidak berdiferensiasi secara optimal sehingga menghasilkan bentuk gigi yang lebih kecil dari normal. Banyak faktor yang memengaruhi terjadinya anomali ukuran gigi, tetapi faktor utama yang memengaruhi anomali pada gigi adalah faktor genetik dan lingkungan. Faktor genetik, memengaruhi benih gigi, yang sifat yang di turunkan oleh gen orang tua, sedangkan faktor lingkungan memengaruhi gigi tersebut setelah erupsi, yaitu bersifat mekanis dan kimiawi. Manifestasi klinis memperlihatkan ukuran mahkota yang lebih kecil, terutama insisif lateral lebih kecil daripada variasi normal disertai bentuk yang mengerucut atau conical teeth (Syarif, 2009). Mikrodontia lebih sering mengenai gigi anterior terutama insisivus lateral yang menyebabkan ukuran gigi lebih kecil daripada variasi normal disertai bentuk yang mengerucut. Diagnosis mikrodontia harus ditegakkan sedini mungkin untuk mengamati dan memelihara perkembangan gigi agar tidak terjadi masalah dikemudian hari (Ivony, 2015).

Mikrodontia umumnya merupakan manifestasi oral dari beberapa sindrom. Banyak sekali sindrom yang mempunyai manifestasi rongga mulut berupa mikrodontia seperti sindrom down (Aparecido, 2016), ektodermal displasia, Silver-Russel, William sindrom, GorlinChaundhry-Moss, dan Coffen-Siris (Shaik, 2016). Sindrom Gorlin-Chaudhry-Moss ditandai dengan gangguan pada pertumbuhan yang membuat tubuh menjadi pendek, terjadi retardasi mental ringan, dan abnormalitas fisik. Sindrom Gorlin-Chaudhry-Moss, terjadi karena penutupan sutura coronalis yaitu sutura terbentuk dari tulang frontal dan tulang parietal dari tengkorak yang prematur sehingga menyebabkan kepala abnormal sehingga mempunyai ukuran lebih pendek (brachiocephaly), manifestasi rongga mulut biasanya terjadi anodontia, hypodontia ataupun oligodontia dan mikrodontia (Krunal, 2018). Sindrom Coffen-Siris adalah kelainan genetik dimana tidak terdapat atau hypoplasia ruas jari terakhir pada ke-5 jari, hypoplasia pada kuku jari, dan kelainan pertumbuhan dengan gambaran tubuh pendek. Sindrom Silver-Russel merupakan sindrom dengan gangguan 
pertumbuhan, gambaran klinis tubuh pendek, pertumbuhan satu sisi berlebih, wajah khas segitiga, dan cacat pada jari kaki. Ectodermal dysplasia adalah kelainan herediter berupa gangguan perkembangan struktur organ-organ yang berasal dari lapisan ektodermal seperti rambut, gigi, kuku, dan kelenjar keringat (Greenwall, 2010).

Perawatan pada gigi mikrodontia dapat dibagi berdasarkan jumlah gigi yang terkena. Perawatan yang dapat dilakukan adalah restoratif estetik, penggunaan piranti ortodontik, dan kombinasi keduanya. Masing-masing pilihan perawatan memiliki keunggulan dan kekurangan masing-masing tergantung kasus yang dihadapi (Laverty, 2016). Restorasi estetik pada gigi anterior merupakan suatu kebutuhan setiap orang. Kemampuan dan pemilihan bahan restorasi sangat menunjang keberhasilan perawatan estetik. Pemilihan bahan harus sesuai dengan kebutuhan estetik dan ketahanan dalam rongga mulut baik ketahanan mekanis ataupun ketahanan kimiawi. Ada beberapa macam perawatan yang dapat dilakukan untuk merawat gigi peg shape secara estetik sebagai berikut.

\section{Resin Komposit}

Penggunaan resin komposit untuk restorasi estetik dapat membuat gigi menjadi ukuran normal dengan cara yang cepat dan mudah. Pertimbangan pemilihan resin komposit adalah karena resin komposit memiliki nilai estetis yang baik, mempunyai perlekatan pada gigi langsung (mikromekanis) yang kuat. Mempunyai kekuatan tensile strength dan compressive strength yang baik. Tetapi pengguaan resin komposit tidak dapat dilakukan sebagai bahan tunggal. Penggunaan resin komposit harus dibarengi dengan bahan lain seperti fiberglass dan bahan lain untuk menunjang kekuatan. Selain itu resin komposit hanya dipakai untuk kasus diastem ringan pada gigi anterior dengan membentuk kembali permukaan mesial dan distal atau menutupi seluruh mahkota dengan bahan tersebut (Alothman, 2018).

\section{Porcelain Veneer}

\begin{tabular}{lrrrr}
\multicolumn{2}{c}{ Pemilihan } & \multicolumn{2}{c}{ perawatan } & \multicolumn{2}{c}{ menggunakan } \\
porcelain & veneer & saat ini & sedang & marak \\
digunakan selain & warnanya yang sangat
\end{tabular}

menyerupai gigi asli, penggunaan veneer juga biokompatibel. Veneer porcelain mempunyai estetik paling baik dibandingkan dengan resin komposit atau GIC. Tetapi pemilihan pengguaan porcelain veneer ini digunakan pada gigi - gigi dengan akar muda dan belum berkembang secara lengkap serta rongga pulpa yang besar. Restorasi jenis ini memiliki resistensi abrasi yang baik, tiidak menyebabkan perubahan oklusi, dan biokompatibel dengan jaringan sekitarnya. Sifat biokompatible dari veneer didapat dari pemakaian porcelain sebagai bahan utama (Rohit, 2016).

\section{Jacket Crown}

Crown dengan bahan porcelain fused metal (PFM). Bahan ini dipilih karena memiliki nilai estetik dan ketahanan terhadap beban kunyah yang tinggi. Kekurangan PFM adalah logam nikel yang biasa digunakan dapat memicu efek alergenik pada pemakai dan efek toksisitas pada teknisi laboratorium dan pemakai protesa dan harga yang tergolong mahal untuk beberapa kalangan (Rahmi, 2019). PFM merupakan salah satu restorasi yang sering digunakan dalam pembuatan mahkota tiruan, restorasi PFM mengkombinasikan 2 logam serta menggunakan kelebihannya untuk mencapai hasil yang maksimal dengan mengkombinasikan kekuatan dari metal tuang dan estetis dari porselen (Mona, 2019).

Indikasi dari PFM adalah terdapat karies atau kerusakan gigi yang luas, trauma, gigi yang memerlukan estetis, untuk pasien yang membutuhkan restorasi yang kuat dan tahan lama namun tidak kalah dalam estetis, gigi yang mengalami malposisi dan ingin di koreksi juga gigi geligi yang sudah mengalami kehilangan banyak struktur gigi pada kasus endodontic (Brezinsky, 2020). Kontraindikasi penggunaan PFM adalah pasien mempunyai penyakit periodontal dan tidak terawat, ruang pulpa yang besar, dan pasien yang mengalami bruxism dan clenching (Rahmi, 2019).

Banyaknya pertimbangan perawatan untuk gigi yang mengalami mikrodontia sehingga banyak pula pilihan yang dapat digunakan oleh dokter gigi untuk merawat gigi dengan berbagai kondisi. Berikut adalah pilihan perawatan mikrodontia dirangkum dari perawatan yang dapat dilakukan pada tabel berikut. 
Tabel 1. Pilihan Perawatan Mikrodontia

\begin{tabular}{ccl}
\hline No & \multicolumn{1}{c}{ Pilihan perawatan } & \multicolumn{1}{c}{ Penjelasan } \\
\hline 1 & $\begin{array}{l}\text { Tidak ada perawatan, pasien } \\
\text { tidak peduli }\end{array}$ & $\begin{array}{l}\text { Dalam kasus dimana pasien puas dengan fungsi dan estetika } \\
\text { gigi yang ada. }\end{array}$ \\
2 & Orthodontik & $\begin{array}{l}\text { Penataan kembali atau reposisi gigi yang diharapkan untuk } \\
\text { mendapatkan ruang guna penempan prostesa. Selain itu } \\
\text { perawatan orthodontic diharapkan dapat menutup diastema. }\end{array}$
\end{tabular}

3 Direct composite

bonding/build-up onto peg

laterals/tooth

$4 \quad$ Indirect composite placement

5 Veneer (Composite/Porcelain)

6 Crowns

7 Crown lengthening

8 Pencabutan dan pemasangan dental implant.

9 Kombinasi perawatan/kombinasi berbagai bidang ilmu kedokteran gigi.
Penempatan restorasi direk sewarna gigi untuk mengubah bentuk dan panjang gigi dan dapat membentuk anatomi mahkota gigi normal.

Pembuatan restorasi warna gigi secara ekstraoral/di laboratorium untuk mendapatkan visualisasi dan adaptasi yang lebih baik dalam merubah gigi. Restorasi tersebut kemudian akan direkatkan ke gigi berbentuk pasak secara intraoral.

Lapisan komposit atau porselen yang direkatkan ke permukaan labial gigi yang sudah terpreparasi.

Mahkota gigi adalah selubung yang berbentuk gigi yang dipasang dan menutupi gigi berguna untuk mengembalikan bentuk dan ukurannya, kekuatannya, dan menyempurnakan penampilannya secara estetis.

Prosedur pembedahan yang dilakukan oleh seorang untuk mengekspos lebih banyak struktur gigi dengan tujuan pemulihan gigi secara prostetik. Sering diindikasikan dalam kasus mahkota klinis yang pendek untuk mendapatkan retensi prostesis di kemudian hari.

Pada kasus gigi yang sudah tidak dapat dipertahankan. Pencabutan merupakan opsi terakhir jika perawatan yang lain sudah tidak dapat dilakukan atau mempunyai prognosis buruk. Gigi yang sudah dicabut dapat langsung dipasangkan implant. Butuh waktu untuk mendapat osseointegrasi dari tulang. Sehingga untuk perawatan ini tidak dapat selesai dalam waktu yang singkat.

Kombinasi perawatan seperti crown lengthening, direct composit dan diikuti oleh perawatan crown.

\section{SIMPULAN}

Perawatan estetis sejatinya sangat diperlukan pada masa sekarang untuk menunjang kepercayaan diri. Pengetahuan dokter gigi akan anatomis gigi geligi, pemilihan warna, dan pemilihan bahan yang beragam sangat dibutuhkan untuk mencapai estetik yang memuaskan. Perawatan estetis yang dapat dilakukan banyak sekali tergantung indikasi dan kontra indikasi serta kemampuan finansial dari pasien. Tingkat kepuasan pasien merupakan cerminan keberhasilan dokter gigi ketika merawat pasiennya, Sehingga untuk mencapai perawatan yang dilakukan tidak hanya memenuhi aspek estetis saja tetapi mengembalikan sistem fonasi dan stomatognasi secara fisiologis. 


\section{DAFTAR PUSTAKA}

Alothman' Y., Bamasoud, M, S. (2018). The Success of Dental Veneers According To Preparation Design and Material Type. $J$ Med Sci 6:(12).

Aparecido, C., Topolski, F., de Faria, L, P., Occhiena, C, M., Ferreira, N,S,P., Ribeiro, F. (2016). Prevalence of Dental Anomalies in Permanent Dentition of Brazilian Individuals with Down Syndrome. J. The open dentistry Journal 3:(1).

Brezinsky, S., Bowles, W., McClanahan, S., Fok, A., \& Ordinola-Zapata, R. (2020). In vitro comparison of porcelain fused to metal crown retention after endodontic access and subsequent restoration: composite, amalgam, amalgam with composite veneer, and fiber post with composite. Journal of Endodontics, 46(11), 1766-1770.

Greenwall, L. (2010). Treatment options for Peg-shaped laterals using direct composite bonding. J. International Dentistry SA. 12:(1).

Gupta, S, P. (2019). Management of Anterior Spacing with Peg Lateral by Interdisciplinary Approach : A Case Report. Orthodontic Journal of Nepal. 9:(1).

Ivony, F. Isti, A., Sumarsongko, t., Bonaficius, S., Rikmasari, R. (2015). Porcelain laminate veneer sebagai perawatan estetik pada gigi insisivus lateralis (Laporan Kasus). Cakradonya Dent J; 12:(2).

Krunal, S., Soni, Satabdi, Saha., Niharika, Subrata, Saha. (2018). Ectodermal Dysplasia: A Case Report. International Journal of Health Sciences \& Research, 8:(9).
Laskaris, G. (2000). Color atlas of oral diseases in children and adolescents. Thieme.

Laverty, D. (2016). The restorative management of microdontia. J. British Dental Journal 221(4).

Malleshi, S. N., Basappa, S., Negi, S., Irshad, A., \& Nair, S. K. (2014). The unusual peg shaped mandibular central incisor-Report of two cases. J Res Pract Dent, 1, 1-6.

Mona, D., Sukartini, E. (2019). Restorasi pasak fiber dan porcelain fused to metal pada fraktur gigi insisif rahang atas pasca perawatan endodontic. Andalas Dental Journal. 1:(1).

Rohit Kulshrestha (2016). Interdisciplinary approach in the treatment of Peg Lateral Incisors. Journal of Orthodontics And Endodontics. 2:1

Rahmi, E., (2019). Replacement of Posterior missing teeth with porcelain fused to metal (PFM) Bridge. Andalas Dental Journal, 1(2), 159-164.

Shaik, M,S., Ibraheem, M,M., Muruganandhan, J., Sujatha, G., Nalin, Kumar., Satish, Kumar. (2016). Non Syndromic True Generalized Microdontia with Multiple Talons Cusp - Unusual Case Report. Journal of Dental and Medical Sciences (IOSR-JDMS) 15:(3).

Syarif, W. (2009). Mikrodontia Insisif Lateral Sebagai Salah Satu Manifestasi Oral Penderita Sindrom Down Tipe Mosaik Dan Penuh. Majalah Kedokteran Bandung, 4l(1). 